\title{
ANALISIS PENERAPAN SUPER DEDUCTION TAX: STUDI KOMPARASI INDONESIA, MALAYSIA, DAN THAILAND
}

\author{
Bina Setyawan ${ }^{1}$, Muhammad Rheza Ramadhan ${ }^{2}$ \\ ${ }^{1}$ Program Studi Diploma-III Pajak, Politeknik Keuangan Negara STAN \\ ${ }^{2}$ Direktorat Jenderal Pajak

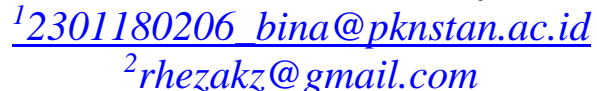

\begin{abstract}
Abstrak
Kemajuan ekonomi suatu bangsa dipengaruhi oleh kualitas sumber daya manusia. Sumber daya manusia yang berkualitas menjadi kekuatan suatu negara dalam persaingan global. Pendidikan merupakan aspek penting dalam meningkatkan kualitas sumber daya manusia. Selain itu, inovasi dan riset merupakan hal yang sangat penting yang perlu didorong untuk kemajuan industri dan perekonomian. Pemerintah mengeluarkan insentif pajak super deduction tax agar Indonesia bisa bersaing secara global. Tujuan dari peneltian ini yaitu menganalisis penerapan super deduction tax di Indonesia dan menganalisis perbandingan penerapan insentif super deduction tax di Indonesia dengan Malaysia dan Thailand. Data dari penelitian ini diperoleh dengan metode studi literatur dan wawancara. Analisis dari data tersebut yaitu setiap negara memiliki kebijakan tarif pengurangan pajak yang berbeda sesuai kebutuhannya dan tentu memiliki fokus kegiatan yang berbeda juga. Hasil penelitian ini dapat dijadikan masukan bagi DJP dalam rangka meningkatkan efisiensi dan efektivitas kebijakan insentif pajak untuk kemajuan perekonomian bangsa.
\end{abstract}

Kata Kunci : sumber daya manusia, super deduction tax, litbang, vokasi

\begin{abstract}
The economic progress of a nation is influenced by the quality of human resources. Quality human resources become the strength of a country in global competition. Education is an important aspect in improving the quality of human resources. In addition, innovation and research are very important things that need to be encouraged for industrial and economic progress. The government has issued a super deduction tax incentive so that Indonesia can compete globally. The purpose of this research is to analyze the application of the super deduction tax in Indonesia and to analyze the comparison of the application of the super deduction tax incentive in Indonesia with Malaysia and Thailand. The data from this research were obtained by using literature study and interview methods. The analysis of the data shows that each country has a different tax reduction rate policy according to its needs and of course has a different focus of activity. The results of this study can be used as a consideration for DGT in order to improve the efficiency and effectiveness of tax incentive policies for the progress of the nation's economy.
\end{abstract}

Keyword : human resources, super deduction tax, $R \& D$, vocational 


\section{PENDAHULUAN}

\subsection{Latar Belakang}

Pandemi Covid-19 melumpuhkan sektor ekonomi di berbagai negara. International Monetary Fund (2020) menetapkan tahun 2020 sebagai The Great Lockdown pada bulan April 2020. Berdasarkan data IMF (2020), ekonomi dunia tahun 2020 lebih buruk daripada The Great Depression 1929 dan Global Financial Crisis 2008. Pertumbuhan ekonomi global di tahun 2020 tumbuh sebesar $-4,9$ persen atau 1,9 persen di bawah perkiraan World Economic Outlook (WEO) pada bulan April 2020. Selain itu, pandemi Covid-19 menaikkan angka kemiskinan global dan tingkat pengangguran yang tidak pernah terjadi dalam beberapa dekade terakhir. Pemulihan ekonomi diproyeksikan terjadi secara bertahap dan membutuhkan waktu yang lama.

Menurut Dipang (2013), sumber daya manusia merupakan aspek penting dalam kemajuan ekonomi. Sumber daya manusia yang berkualitas menjadi kekuatan suatu negara dalam persaingan global. Berdasarkan data World Bank (2020), nilai Human Capital Index Indonesia hanya sebesar 0,54 persen. Dari 157 negara, Indonesia menempati peringkat 87. Pencapaian Indonesia berada di bawah negara tetangga seperti Thailand dan Malaysia.

Berdasarkan penilaian Programme for International Student Assessment (2018), pengetahuan matematika, sains, dan literasi masyarakat Indonesia masih dibawah rata-rata OECD. Padahal, perkembangan sumber daya manusia sangat dipengaruhi oleh kualitas pendidikan. Studi PISA (2018) diikuti oleh sebanyak 79 negara. Indonesia menempati peringkat 73 dengan nilai 379 kategori matematika, peringkat 71 dengan nilai 396 kategori sains, dan peringkat 74 dengan nilai 371 kategori literasi. Lebih lanjut, terjadi penurunan performa Indonesia dibandingkan laporan PISA (2015) padahal indikator dan metode yang digunakan sama.

Selain berupaya untuk meningkatkan kualitas pendidikan, pemerintah harus memperhatikan inovasi industri. Menurut Sembodo (2020, dikutip dalam website Kementerian PPN/Bappenas, 2020), Indonesia masih kesulitan dalam menghadapi transformasi baik dari sisi SDM maupun teknologi. Inovasi dan riset menjadi aspek penting yang harus terus didorong untuk mengimplementasikan kemajuan industri 
4.0. Salah satu langkah untuk mendukung transformasi digital yaitu dengan mengoptimalkan penggunaan anggaran research and development.

Berdasarkan data World Bank (n.d.), besarnya anggaran R\&D Indonesia dari tahun ke tahun sebenarnya sudah mengalami kenaikan. Namun, anggaran Indonesia untuk sektor litbang masih tergolong rendah, yaitu berkisar 0,23 persen dari PDB. Bahkan, lebih rendah dibandingkan beberapa negara tetangga seperti Singapura (1,94\%), Malaysia (1,44\%), Thailand (1\%), dan Vietnam (0,53\%). Negara dengan tingkat anggaran R\&D yang tinggi cenderung maju dalam perekonomiannya seperti Swiss, Jepang, Finlandia, dan Amerika Serikat.

Untuk meningkatkan kualitas sumber daya manusia, Pemerintah Indonesia mengeluarkan kebijakan yaitu PMK 128/PMK.010/2019. PMK ini mengatur mengenai penyelenggaraan kegiatan praktik kerja, pemagangan, dan/atau pembelajaran dalam rangka pembinaan dan pengembangan sumber daya manusia yang diberikan insentif berupa pengurangan penghasilan bruto untuk mengurangi pajak terutang yang dibayar. Praktik kerja atau pemagangan merupakan kegiatan yang dilakukan wajib pajak di tempat usaha dengan membangun workplace learning and training. Pembelajaran merupakan kegiatan pengajaran yang dilakukan oleh wajib pajak di instansi pendidikan seperti sekolah menengah kejuruan, perguruan tinggi diploma, dan lain-lain.

Untuk menunjang kegiatan R\&D terutama saat kondisi pandemi Covid-19 ini, Pemerintah Indonesia mengeluarkan peraturan terbaru terkait R\&D yaitu PMK 153/PMK.010/2020. Berdasarkan PMK tersebut, terdapat 11 sektor industri yang mendapat fasilitas pengurangan penghasilan bruto sampai $300 \%$ terkait dengan litbang. Salah satu industri yang menjadi fokus terkait dengan kegiatan R\&D adalah farmasi terutama terkait dengan penelitian dan pengembangan bahan farmasi, industri fitofarmaka, alat kesehatan dan laboratorium, dan lain-lain.

Penerapan insentif pajak jumbo di Indonesia masih banyak kekurangan. Menurut Adhinegara (2019, dikutip dalam website iNews.id, 2019), sangat sedikit perusahaan yang mau masuk ke sektor padat karya dan berinvestasi di SDM dalam kondisi saat ini. Perusahaan lebih memilih outsourcing SDM ke negara lain seperti India karena biaya yang lebih murah dan teruji kualitasnya. Selain itu, mekanisme 
klaim terkait insentif pajak jumbo ini tidak mudah karena industri yang mengajukan insentif harus melalui banyak tahapan seperti pengawasan sampai audit laporan keuangan serta bersih catatan pajaknya. Di sisi lain, menurut Irwanto (2020), Malaysia sukses mengimplementasikan insentif pajak litbang dengan dibuktikan status negara tersebut yang hampir mencapai negara berpenghasilan tinggi (high income country). Kelebihan pengeluaran $\mathrm{R} \& \mathrm{D}$ yang melebihi pendapatan baik dilakukan di Malaysia maupun di luar Malaysia bisa dilakukan dikompensasi ke tahun berikutnya. Sementara itu, di Thailand, banyak upaya yang diberikan oleh pemerintah negara tersebut dengan memberikan kemudahan untuk perusahaan dalam memanfaatkan insentif litbang (Darussalam \& Tobing, 2013).

\subsection{Rumusan Masalah}

1. Bagaimana penerapan super deduction tax di Indonesia?

2. Bagaimana perbandingan penerapan insentif super deduction tax di Indonesia dengan di Malaysia dan Thailand?

\subsection{Tujuan Penulisan}

1. Untuk menganalisis penerapan super deduction tax di Indonesia.

2. Untuk menganalisis perbandingan penerapan insentif super deduction tax di Indonesia dengan di Malaysia dan Thailand.

\section{TINJAUAN PUSTAKA}

\subsection{Pemagangan}

Daryanto (2009) mengemukakan bahwa magang atau praktik kerja lapangan merupakan bentuk penyelenggaraan pendidikan keahlian profesional yang memadukan antara program pendidikan di sekolah dan program penguasaan keahlian yang diperoleh melalui kegiatan bekerja secara langsung di dunia kerja (on the job training) secara terarah untuk mencapai suatu tingkat keahlian profesional tertentu.

Menurut Mondy (2008), magang merupakan bentuk khusus perekrutan yang melibatkan penempatan siswa/mahasiswa pada pekerjaan sementara tanpa adanya kewajiban bagi perusahaan/instansi untuk mempekerjakan 
siswa/mahasiswa tersebut secara tetap maupun kewajiban memberi peserta magang tersebut posisi tetap dalam perusahaan/instansi setelah yang bersangkutan lulus.

Pemerintah telah mengatur hal-hal mengenai pemagangan yang diselenggarakan oleh perusahaan dalam Peraturan Menteri Ketenagakerjaan Nomor 36 Tahun 2016 tentang Penyelenggaraan Pemagangan Dalam Negeri. Pasal 1 Ayat 1 peraturan tersebut menjelaskan pemagangan merupakan bagian dari sistem pelatihan kerja yang diselenggarakan secara terpadu antara pelatihan di lembaga pelatihan dengan bekerja secara langsung di bawah bimbingan dan pengawasan instruktur atau pekerja yang lebih berpengalaman dalam proses produksi barang dan atau jasa di perusahaan, dalam rangka menguasai keterampilan atau keahlian tertentu. Penyelenggara pemagangan adalah perusahaan yang memenuhi persyaratan untuk menyelenggarakan pemagangan.

Pasal 1 Ayat 3 menjelaskan perusahaan adalah setiap bentuk usaha yang berbadan hukum atau tidak, milik orang perseorangan, milik persekutuan, atau milik badan hukum, baik milik swasta maupun milik negara yang mempekerjakan pekerja dengan membayar upah atau imbalan dalam bentuk lain. Selain itu, perusahaan dalam lingkup bahasan ini merupakan usaha-usaha sosial dan usahausaha lain yang mempunyai pengurus dan mempekerjakan orang lain dengan membayar upah atau imbalan dalam bentuk lain.Pasal 1 Ayat 4 menjelaskan unit pelatihan menyelenggarakan adalah satuan unit yang pelatihan di perusahaan baik untuk memenuhi kebutuhan sendiri maupun kebutuhan masyarakat.

\subsection{Penelitian dan Pengembangan}

Hal-hal pembahasan mengenai penelitian dan pengembangan dijelaskan dalam Undang-Undang Nomor 11 Tahun 2019 tentang Sistem Nasional Ilmu Pengetahuan dan Teknologi. Dalam. Pasal 1 dijelaskan bahwa Sistem Nasional Ilmu Pengetahuan dan Teknologi adalah pola hubungan yang membentuk keterkaitan secara terencana, terarah, dan terukur, serta berkelanjutan antarunsur kelembagaan dan sumber daya sehingga terbangun jaringan ilmu pengetahuan dan teknologi sebagai satu kesatuan yang utuh dalam mendukung penyelenggaraan ilmu 
pengetahuan dan teknologi sebagai landasan ilmiah dalam perumusan dan penetapan kebijakan pembangunan nasional. Penyelenggaraan ilmu pengetahuan dan teknologi adalah proses, cara , dan/atau aktivitas menyelenggarakan kegiatan pendidikan, penelitian, pengembangan, pengkajian, dan penerapan ilmu pengetahuan dan teknologi. Pendidikan adalah usaha sadar dan terencana untuk mewujudkan suasana belajar dan proses pembelajaran agar peserta didik secara aktif mengembangkan potensi dirinya untuk memiliki kekuatan spiritual keagamaan, pengendalian diri, kepribadian, kecerdasan, akhlak mulia, serta keterampilan yang diperlukan dirinya, masyarakat, bangsa, dan negara.

Menurut Sugiyono (2012), metode penelitian yang digunakan untuk menghasilkan produk tertentu merupakan jenis penelitian pengembangan (research and development). Untuk dapat menghasilkan produk tertentu, digunakan penelitian bersifat analisis kebutuhan. Penelitian dan pengembangan adalah suatu proses atau langkah-langkah untuk mengembangkan suatu produk baru atau menyempurnakan produk yang telah ada, yang dapat dipertanggungjawabkan. Sedangkan, menurut Borg dan Gall (1983, sebagaimana dikutip dalam Punaji Setyosari, 2010), pengertian penelitian pengembangan adalah suatu proses yang dipakai untuk mengembangkan dan memvalidasi produk penelitian.

Pasal 1 Ayat 7 UU Nomor 11 Tahun 2019 menjelaskan penelitian adalah kegiatan yang dilakukan menurut metodologi ilmiah untuk memperoleh data dan informasi yang berkaitan dengan pemahaman tentang fenomena alam dan/atau sosial, pembuktian kebenaran atau ketidakbenaran suatu asumsi dan/atau hipotesis, dan penarikan kesimpulan ilmiah. Sementara itu, Pasal 1 Ayat 8 menjelaskan bahwa pengembangan adalah kegiatan untuk peningkatan manfaat dan daya dukung ilmu pengetahuan dan teknologi yang telah terbukti kebenaran dan keamanannya untuk meningkatkan fungsi dan manfaat ilmu pengetahuan dan teknologi. Dalam Pasal 16 dijelaskan penyelenggaraan ilmu pengetahuan dan teknologi melalui pendidikan dilaksanakan dalam rangka meningkatkan kapasitas bangsa dalam mengelola sumber daya dan diutamakan untuk memenuhi kebutuhan nasional agar dapat meningkatkan daya saing serta mewujudkan kemandirian bangsa. 
Dalam Pasal 19 dijelaskan bahwa penelitian dilaksanakan untuk penguatan penguasaan ilmu dasar dan ilmu terapan, termasuk di dalamnya. ilmu sosial yang digunakan untuk menciptakan dan/atau mengernbangkan ilmu pengetahuan dan, teknologi. Selain itu, penelitian juga dapat menjadi solusi permasalahan pembangunan. Dalam Pasal 20, Pengembangan dilaksanakan sebagai tindak lanjut dari penelitian untuk meningkatkan kesejahteraan masyarakat dan memajukan peradaban. Hasil penelitian dan pengembangan wajib dipublikasikan dan didiseminasikan oleh sumber daya manusia, ilmu pengetahuan dan teknologi dan/atau kelembagaan ilmu pengetahuan dan Teknologi. kecuali dinyatakan lain oleh peraturan perundang-undangan.

\section{METODE PENELITIAN}

\subsection{Metode Penelitian Kepustakaan}

Studi kepustakaan yaitu kegiatan untuk menghimpun informasi yang relevan dengan topik atau masalah yang menjadi objek penelitian. Metode ini dilaksanakan dengan mempelajari sejumlah literatur berupa buku, karya ilmiah, tesis, disertasi, ensiklopedia, internet, jurnal, artikel, peraturan perundangundangan, serta data dari website yang terpercaya untuk memperoleh dasar teoritis mengenai permasalahan yang akan dibahas dalam jurnal ini.

Metode ini merupakan sumber utama penulis dalam penulisan jurnal. Untuk membandingkan kebijakan perpajakan antarnegara, penulis perlu melakukan kajian mendalam terkait dengan peraturan-peraturan yang dikeluarkan oleh pemerintah negara yang bersangkutan.

Terkait dengan studi kepustakaan, data yang diperoleh merupakan data sekunder karena data yang diperlukan telah ada sebelumnya dan digunakan oleh peneliti untuk melengkapi kebutuhan data penelitian.

\subsection{Metode Penelitian Kualitatif}

Metode penelitian kualitatif yang digunakan oleh penulis adalah wawancara. Wawancara digunakan untuk memperoleh informasi tambahan dari pembuat kebijakan, tokoh ahli,maupun akademisi. Penulis telah melakukan 
wawancara kepada tiga orang. Pihak pertama yang menjadi narasumber yaitu Bapak Candra sebagai pegawai Direktorat Peraturan Perpajakan II DJP selaku pembuat peraturan perpajakan. Pihak kedua yang menjadi narasumber yaitu Bapak Purwitohadi sebagai Pejabat Fungsional Pusat Kebijakan Pendapatan Negara Badan Kebijakan Fiskal (BKF). Pihak ketiga yang menjadi narasumber yaitu Bapak Sulfan sebagai akademisi PKN STAN. Wawancara dilaksanakan secara daring karena kondisi pandemi Covid-19 yang tidak memungkinkan untuk datang langsung ke lokasi. Terkait dengan wawancara, data yang diperoleh merupakan data primer karena data tersebut diambil langsung dari tokoh ahli.

\section{HASIL DAN PEMBAHASAN}

\subsection{Insentif Super Deduction Tax di Indonesia}

\subsubsection{Asal Mula Insentif Super Deduction Tax}

Berdasarkan wawancara yang dilakukan oleh penulis terhadap Bapak Sulfan, Akademisi PKN STAN, insentif super deduction tax sangat dibutuhkan untuk mendorong penelitian mengenai high technology karena belum banyak perusahaan-perusahaan nasional yang melakukan hal tersebut. Selama ini, perkembangan industri mengalami hambatan karena belum ada dukungan dari pemerintah terkait masalah perpajakan terutama berkaitan dengan fasilitas insentif untuk kegiatan litbang. Fasilitas diperlukan untuk menciptakan iklim kompetitif internasional. Negara-negara tetangga seperti Malaysia dan Vietnam sudah memberikan fasilitas tersebut terlebih dahulu. Insentif pajak super deduction tax diharapkan bisa mendorong kegiatan litbang sehingga perusahaan di Indonesia bisa menggunakan teknologi yang memang berasal dari penelitian sendiri dan sesuai dengan kebutuhan DUDI dan tentunya bisa bersaing dengan teknologi yang berasal dari luar negeri.

Menurut Bapak Purwitohadi, Pegawai Fungsional BKF, litbang sangat penting untuk keberlanjutan inovasi SDM dan berpotensi memperbesar pendapatan devisa negara melalui paten yang dimiliki. Perusahaan-perusahaan di Indonesia masih memanfaatkan teknologi dan intellectual property right dari luar negeri. Negara mendapatkan sedikit manfaat dari pembayaran royalti ke negara lain 
padahal jumlahnya sangat besar. Peran serta swasta sangat dibutuhkan karena saat ini anggaran terkait litbang sebagian besar masih berasal dari APBN. Di negara maju, peran swasta sangat besar. Swasta punya andil yang besar untuk menciptakan pasar yang kompetitif dan menghasilkan produk yang harganya terjangkau dan berorientasi ekspor. Sebenarnya, Indonesia sudah memiliki banyak peneliti di unit litbang pemerintah. Peneliti-peneliti memiliki berbagai inovasi dan sudah ada yang dipatenkan. Namun, belum banyak industri yang melirik dan memakai karena tidak ada kesinkronan antara kebutuhan industri dan hasil yang dilakukan oleh peneliti.

Pada awalnya, pemerintah mengeluarkan KMK 769/KMK.04/1990 tentang perlakuan pajak atas biaya litbang. Yang dimaksud biaya litbang yaitu biaya untuk pengembangan produk dan untuk meningkatkan efisiensi perusahaan seperti teknologi yang digunakan dalam pengembangan proses. Untuk mendorong investasi industri padat kerja, Pemerintah RI mengeluarkan Peraturan Pemerintah Nomor 45 Tahun 2019. Peraturan ini bertujuan untuk menciptakan lapangan kerja mendorong pelaksanaan kegiatan litbang, mendorong keterkaitan antara pendidikan dengan dunia usaha dan dunia industri (DUDI), dan meningkatkan kualitas sumber daya manusia. Peraturan ini merupakan kebijakan pemerintah pertama terkait insentif super deduction tax atau insentif pajak yang memberikan pengurangan melebihi 100\% dari biaya yang dikeluarkan. Dalam Bab VIII Peraturan Pemerintah Nomor 45 Tahun 2019, diatur mengenai pemberian fasilitas baik pengurangan penghasilan neto dalam investasi maupun pengurangan penghasilan bruto dalam kegiatan tertentu yaitu pengurangan penghasilan neto sebesar $60 \%$ dari penanaman modal aktiva tetap berwujud untuk wajib pajak industri padat karya, pengurangan penghasilan bruto hingga $200 \%$ dari biaya untuk praktik kerja/pemagangan, dan pengurangan penghasilan bruto hingga $300 \%$ dari biaya untuk kegiatan litbang tertentu di Indonesia.

\subsubsection{Insentif Pajak Vokasi berdasarkan PMK Nomor 128/PMK.010/2019}

PMK 128/PMK.010/2019 memberikan fasilitas pengurangan insentif super deduction tax sebagai berikut.

1. Pengurangan penghasilan bruto hingga $200 \%$ dengan rincian pengurangan penghasilan bruto sebesar $100 \%$ dari jumlah biaya yang dikeluarkan dan 
tambahan pengurangan penghasilan bruto sebesar $100 \%$ dari jumlah biaya yang dikeluarkan.

2. Tambahan penghasilan bruto dapat dimanfaatkan dengan ketentuan wajib pajak telah melakukan kegiatan praktik kerja, pemagangan, dan/ atau pembelajaran sesuai kompetensi yang diajarkan di sekolah menengah kejuruan/ madrasah aliyah kejuruan, perguruan tinggi diploma pada program vokasi , maupun balai latihan kerja, memiliki Perjanjian Kerja Sama, sudah menyampaikan Surat Keterangan Fiskal, dan tidak dalam keadaan rugi fiskal pada tahun pajak pemanfaatan insentif.

3. Biaya untuk kegiatan praktik kerja, pemagangan, atau pembelajaran yang mendapat pengurangan penghasilan bruto meliputi biaya penyediaan fasilitas fisik khusus berupa tempat pelatihan dan biaya penunjang fasilitas fisik khusus berupa bahan bakar, listrik, biaya pemeliharaan, dan air. Selain itu, biaya lainnya untuk pelaksanaan praktik kerja atau pemagangan antara lain biaya instruktur atau pengajar sebagai tenaga pembimbing, barang atau bahan yang diperlukan dalam praktik kerja, pemagangan, dan/atau pembelajaran, honorarium atau pembayaran dan sertifikasi kompetensi yang diberikan kepada siswa, mahasiswa, peserta latih, perorangan yang tidak terikat hubungan kerja, pendidik, tenaga pendidikan, dan instruktur.

4. Tambahan pengurangan penghasilan bruto diberikan dalam beberapa hal yang diatur pemerintah antara lain.

a. Biaya perolehan barang berwujud dan tidak berwujud yang memiliki masa manfaat lebih dari satu tahun untuk penyediaan fasilitas fisik dihitung dari biaya amortisasi atau penyusutan barang yang dibebankan saat kegiatan pelaksanaan praktik kerja atau pemagangan.

b. Biaya penyediaan fasilitas khusus berupa tempat pelatihan yang merupakan barang berwujud yang masa manfaatnya lebih dari satu tahun dan tidak digunakan penuh dalam satu tahun pajak dibebankan secara proporsional berdasarkan waktu pemanfaatan.

c. Biaya penyediaan fasilitas khusus berupa tempat pelatihan yang merupakan biaya listrik, air, dan bahan bakar yang tidak dipisahkan antara 
tujuan komersial dan kegiatan praktik kerja atau pemagangan dibebankan secara proporsional berdasarkan pemanfaatan terkait dengan praktik kerja atau pemagangan.

d. Untuk biaya selain yang telah disebutkan, tambahan pengurangan penghasilan bruto dihitung berdasarkan biaya sesungguhnya yang dikeluarkan dan dibebankan pada tahun pajak bersangkutan.

e. Tambahan pengurangan penghasilan bruto dapat dibebankan sebagai biaya sepanjang tidak menyebabkan rugi fiskal pada tahun berjalan. Jika menyebabkan rugi fiskal tahun berjalan, tambahan pengurangan yang dapat dikurangkan sebesar jumlah yang tidak menyebabkan rugi fiskal pada tahun berjalan.

5. Tambahan pengurangan penghasilan bruto tidak dapat diberikan dalam beberapa hal berikut.

a. Biaya yang diberikan kepada peserta praktik kerja atau pemagangan yang memiliki hubungan usaha, keluarga sedarah dalam garis keturunan lurus satu derajat, atau kepenguasaan dengan pemilik, komisaris, maupun pengurus wajib pajak.

b. Tambahan pengurangan penghasilan bruto berupa fasilitas fisik tidak dapat digunakan dalam hal merupakan bagian dari penanaman modal yang telah mendapatkan fasilitas pengurangan penghasilan neto sebagaimana dalam Pasal 29A Peraturan Pemerintah Nomor 45 Tahun 2019 dan Pasal 31A Undang-Undang Nomor 36 Tahun 2008.

4.1.3 Insentif Pajak Litbang berdasarkan PMK Nomor 153/PMK.010/2020

PMK Nomor 153/PMK.010/2020 memberikan fasilitas pengurangan insentif super deduction tax sebagai berikut.

1. Fasilitas pengurangan kegiatan litbang tertentu di Indonesia hingga 300\% dengan rincian pengurangan penghasilan bruto sebesar 100\% dari jumlah biaya yang dikeluarkan dan tambahan pengurangan penghasilan bruto hingga sebesar $200 \%$ dari total jumlah biaya yang dikeluarkan.

2. Tambahan pengurangan penghasilan bruto terdiri atas pengurangan sebesar: 
a. 50\% jika litbang menghasilkan hak kekayaan intelektual berupa paten atau hak perlindungan varietas tanaman (PVT) yang telah didaftarkan di kantor paten atau PVT dalam negeri;

b. $25 \%$ jika litbang menghasilkan paten atau hak PVT selain yang telah didaftarkan di kantor paten atau PVT dalam negeri;

c. $100 \%$ jika litbang telah mencapai tahap komersialisasi; dan/atau

d. $25 \%$ jika litbang yang telah mencapai tahap komersialisasi dilakukan melalui kerja sama dengan lembaga litbang pemerintah atau lembaga tinggi di Indonesia.

3. Kegiatan litbang tertentu yang dapat diberikan tambahan pengurangan yaitu:

a. litbang yang dilakukan oleh wajib pajak, selain wajib pajak yang menjalankan usaha berdasarkan kontrak karya, kontrak bagi hasil, atau perjanjian kerjasama usaha pertambangan yang ketentuan perpajakannya memiliki perhitungan tersendiri;

b. bertujuan untuk memperoleh penemuan baru, berdasarkan konsep orisinal, terencana dan teranggarkan, memiliki hasil akhir yang belum bisa dipastikan, dan bertujuan untuk menciptakan sesuatu yang bisa dijual di pasar;

c. litbang dapat diberikan dalam hal prioritas kegiatan sesuai dengan fokus yang tercantum dalam PMK antara lain pangan, farmasi dan alat kesehatan, tekstil, kulit, alas kaki, alat transportasi, energi, elektronika, agroindustri, barang modal dan bahan penolong, pertahanan dan keamanan, logam dasar dan bahan galian nonlogam, dan kimia dasar berbasis migas batubara.

4. Biaya litbang yang dapat diberikan pengurangan meliputi biaya terkait dengan:

a. aktiva selain tanah dan bangunan berupa biaya penyusutan atau amortisasi dan biaya penunjang yaitu listrik, air, bahan bakar, dan pemeliharaan;

b. barang atau bahan;

c. gaji, honor, atau pembayaran sejenis untuk peneliti atau perekayasa; 

d. pengurusan untuk mendapatkan hak kekayaan intelektual; dan
e. imbalan kepada lembaga litbang atau lembaga pendidikan tinggi di Indonesia.

5. Biaya dibebankan berdasarkan proposal kegiatan litbang. Untuk biaya yang tidak dipisahkan berdasarkan proposal kegiatan litbang, pembebanan dilakukan secara proporsional berdasarkan waktu penugasan atau pemanfaatan.

6. Tambahan penghasilan bruto dapat dimanfaatkan sebesar persentase tambahan pengurangan dikali dengan total biaya litbang terkait untuk lima tahun pajak terakhir sejak saat pendaftaran hak kekayaaan intelektual atau mencapai tahap komersialisasi. Besaran tambahan pengurangan yang dapat dibebankan setiap tahun paling tinggi yaitu $40 \%$ dari penghasilan kena pajak sebelum dikurangi tambahan pengurangan penghasilan bruto. Jika tambahan pengurangan penghasilan melebihi $40 \%$ dalam satu tahun pajak, selisih lebih tambahan pengurangan penghasilan bruto yang belum dimanfaatkan bisa diperhitungkan untuk tahun pajak berikutnya.

7. Wajib pajak yang melakukan kegiatan litbang wajib mendaftarkan hak kekayaan intelektual berupa paten atau hak PVT:

a. atas nama wajib pajak yang menerima fasilitas pengurangan; atau

b. atas nama bersama wajib pajak yang melakukan kerjasama litbang di Indonesia.

\subsubsection{Pemanfaatan Insentif Super Deduction Tax}

Berdasarkan data yang penulis peroleh dari wawancara terhadap Bapak Candra, Pegawai Direktorat Perpajakan II DJP, total sudah terdapat 41 wajib pajak memanfaatkan insentif super deduction tax hingga tanggal 31 Maret 2021. Sebanyak 29 wajib pajak memanfaatkan insentif pajak vokasi PMK 128 dengan total 235 Perjanjian Kerja Sama yang memenuhi ketentuan. Perjanjian Kerja Sama (PKS) tersebut berasal dari mitra wajib pajak dengan rincian sebanyak 189 PKS berasal dari SMK, 31 PKS berasal dari Diploma, dan 15 PKS berasal dari Balai Latihan Kerja / Dinas. Pemanfaatan insentif ini diikuti oleh 27.805 peserta dengan estimasi biaya mencapai Rp638 miliar. Terdapat empat sektor usaha yang menjadi 
fokus pemanfaatan insentif yaitu manufaktur, pariwisata dan industri kreatif, agrobisnis, dan kesehatan.

Wajib pajak yang memanfaatkan insentif pajak litbang berdasarkan PMK 153 berjumlah 12 WP. Terdapat 106 proposal litbang yang telah diajukan WP dan memenuhi ketentuan PMK ini. Estimasi total biaya yang dikeluarkan oleh wajib pajak sebesar Rp1031,05 miliar. Ada enam fokus sektor usaha yang diajukan untuk mendapatkan insentif pajak antara lain pangan, farmasi dan kosmetik, kimia dasar migas dan batu bara, logam dasar dan bahan galian bukan logam, energi, dan elektronika dan telematika.

\subsection{Perbandingan Insentif Super Deduction Tax di Indonesia dengan Negara Malaysia dan Thailand}

4.2.1 Definisi dan Perlakuan Insentif Super Deduction Tax Masing-Masing Negara KMK 769/KMK.04/1990 mendefinisikan pengertian penelitian dan pengembangan di Indonesia untuk kepentingan perpajakan menjadi dua kegiatan yaitu pengembangan produk (product development) dan kegiatan untuk meningkatkan efisiensi perusahaan termasuk teknologi untuk pengembangan proses (process technology). Jika kegiatan yang dilakukan oleh wajib pajak memenuhi definisi tersebut, wajib pajak boleh memanfaatkan insentif R\&D secara fiskal.

Promotion of Investments Act 1986 Malaysia mendefinisikan penelitian dan pengembangan (R\&D) sebagai setiap studi sistematis atau intensif yang dilakukan di bidang sains atau teknologi dengan tujuan menggunakan hasil studi untuk produksi atau peningkatan bahan, perangkat, produk, produksi atau proses tetapi tidak termasuk:

a. kontrol kualitas produk atau pengujian rutin bahan, perangkat, produk atau produk;

b. penelitian dalam ilmu sosial atau humaniora;

c. pengumpulan data rutin;

d. survei efisiensi atau studi manajemen; dan

e. riset pasar atau promosi penjualan. 
Di Malaysia, perusahaan di berbagai industri telah didorong oleh pemerintah untuk memulai R\&D agar tetap bertahan di tengah kompetitif global. Salah satu langkah dalam mendorong R\&D di kalangan bisnis di Malaysia adalah insentif dalam bentuk.

a. Ketentuan khusus di bawah Pasal 34(7) Income Tax Act 1967 berupa single deduction.

b. Pengurangan khusus berdasarkan Pasal 34(A) Income Tax Act 1967 berupa double deduction.

c. Pengurangan khusus berdasarkan Pasal 34(B) Income Tax Act 1967 berupa double deduction.

Definisi penelitian dan pengembangan di Thailand mengacu pada OECD Frascati Manual. Menurut OECD (2015), penelitian dan pengembangan (R\&D) terdiri dari pekerjaan kreatif yang dilakukan secara sistematis dalam rangka menambah bekal ilmu, termasuk ilmu manusia, budaya dan masyarakat, dan penggunaan pengetahuan untuk merancang aplikasi baru. Suatu kegiatan termasuk R\&D apabila memenuhi kategori berikut.

a. Riset dasar (basic research), yaitu studi teoritis atau penelitian di laboratorium untuk mencari pengetahuan baru tanpa pengembangan produk atau layanan.

b. Riset terapan (applied research), yaitu sebuah studi untuk mencari pengetahuan baru dengan tujuan menerapkan hasil yang diperoleh dari penelitian ke dalam praktik atau untuk mencari alternatif baru untuk mendapatkan tujuan yang diinginkan.

c. Riset pengembangan eksperimental (experimental development research), yaitu studi sistematis memanfaatkan pengetahuan dan informasi yang diketahui untuk menciptakan sumber daya, alat, produk baru, proses, sistem, atau layanan, atau untuk mengembangkan dan meningkatkan proses yang ada.

\subsubsection{Biaya yang Deductible}

Di Indonesia, biaya yang dapat dibebankan untuk kegiatan litbang berdasarkan KMK 769/KMK.04/1990 yaitu biaya untuk pengembangan produk dan untuk meningkatkan efisiensi perusahaan termasuk teknologi yang digunakan dalam pengembangan proses. Sementara itu, biaya yang dapat dibebankan 
berdasarkan PMK 128/PMK.010/2019 antara lain biaya penyediaan fasilitas fisik khusus berupa tempat pelatihan dan biaya penunjang fasilitas fisik khusus berupa bahan bakar, listrik, biaya pemeliharaan, dan air serta biaya lainnya.

Di Malaysia, berdasarkan Income Tax Act 1967, pengeluaran yang memenuhi syarat untuk insentif R\&D mencakup gaji, perlengkapan, layanan teknis, biaya teknis, biaya transportasi, biaya pemeliharaan, sewa, dan pengeluaran lain yang dikeluarkan secara langsung untuk pelaksanaan penelitian yang memenuhi syarat. Sementara itu, terkait dengan vokasi biaya yang bisa dibebankan yaitu biaya terkait pelatihan teknis atau kejuruan dan kursus sains yang memenuhi syarat.

Di Thailand, suatu kegiatan termasuk R\&D dan bisa dibebankan apabila biaya tersebut terkait dengan penelitian dasar, penelitian terapan, dan penelitian pengembangan eksperimental sesuai OECD Frascati Manual. Sementara itu, biaya terkait vokasi yang bisa dibebankan berdasarkan Royal Decree No. 711,712, dan 713 antara lain biaya gaji karyawan yang memiliki keahlian dan keterampilan, biaya pendidikan atau pelatihan karyawan, dan biaya sumbangan ke institusi pendidikan.

\subsubsection{Jenis Insentif}

Indonesia telah mengatur insentif pajak terkait litbang di dalam PMK 153/PMK.010/2020 yang berisi mengenai pengurangan penghasilan bruto paling tinggi 300\% (triple deduction) dari biaya yang dikeluarkan untuk kegiatan litbang tertentu di Indonesia. Sementara itu, insentif pajak terkait vokasi tertuang dalam PMK No.128/PMK.010/2019 yang berisi mengenai pengurangan penghasilan bruto paling tinggi 200\% (double deduction) dari biaya yang dikeluarkan untuk kegiatan vokasi tertentu di Indonesia.

Malaysia telah mengatur insentif pajak terkait litbang di dalam Pasal 34(7), 34A dan 34B Income Tax Act 1967. Untuk mengatur lebih lanjut terkait kegiatan litbang, pada tanggal 13 Agustus 2020 Malaysia menerbitkan dua kebijakan Public Ruling baru yaitu Public Ruling No.5/2020 tentang qualifying research and development activity dan Public Ruling No.6/2020 tentang special deductions. PR 5/2020 dan PR 6/2020 menggantikan peraturan sebelumnya yaitu Public Ruling 
No.5/2004 tentang double deduction incentive on research expenditure and its addendum.

Berdasarkan PR 5/2020, seseorang akan memenuhi syarat untuk mengklaim insentif dalam bentuk single atau double deduction untuk pengeluaran yang diizinkan dalam kegiatan R\&D jika semua kondisi berikut terpenuhi yaitu orang tersebut harus:

a. menjadi penduduk untuk tujuan perpajakan di Malaysia;

b. menjalankan bisnis di Malaysia;

c. melakukan aktivitas R\&D sehubungan dengan bisnisnya di Malaysia yaitu

(i) untuk keperluan internal (in-house) dalam bisnisnya; atau

(ii) melakukan aktivitas outsourcing ke lembaga penelitian atau perusahaan yang disetujui, atau sebuah perusahaan $R \& D$ atau perusahaan $R \& D$ kontrak di Malaysia;

d. melakukan aktivitas R\&D yang memenuhi definisi $R \& D$, dan kriteria kualifikasinya;

e. mendapatkan persetujuan untuk kegiatan R\&D dari Director General of Inland Revenue of Malaysia (DGIR) dimana Menteri Keuangan telah mendelegasikan kewenangan tersebut kepada DGIR jika klaim pemotongan ganda berada di bawah Pasal 34A dari ITA; atau

f. menggunakan layanan lembaga atau perusahaan yang disetujui oleh menteri terkait jika pemotongan ganda yang diklaim sesuai dengan Pasal 34B ITA.

PR 6/2020 mengatur lebih lanjut mengenai ketentuan klaim insentif single deduction berdasarkan Pasal 34(7) ITA dan double deduction berdasarkan pasal 34A dan 34B ITA. Pasal 34(7) berisi mengenai single deduction for research and development expenditure. Untuk memastikan pendapatan yang disesuaikan seseorang dari bisnis untuk periode dasar untuk satu tahun penilaian, pengurangan tunggal sejumlah pengeluaran (bukan belanja modal) yang terjadi pada R\&D yang memenuhi syarat aktivitas diperbolehkan. Belanja modal berarti pengeluaran yang terjadi untuk:

a. pabrik, mesin, perlengkapan, tanah, tempat atau bangunan; 
b. struktur atau karya yang bersifat permanen atau pada perubahan,tambahan atau perluasannya; atau

c. akuisisi hak apapun atas properti apapun.

Pasal 34A berisi mengenai special deduction for research and development expenditure (pengurangan khusus untuk kegiatan litbang). Berdasarkan pasal ini, untuk menyesuaikan pendapatan seseorang yang berasal dari bisnis untuk periode satu tahun penilaian, sebuah pengurangan atau deduction dapat diberikan dari pendapatan kotor bisnis untuk periode itu yang berkenaan dengan pengeluaran dan bukan merupakan pengeluaran modal yang dikeluarkan oleh orang tersebut dalam jangka waktu penelitian dan pengembangan yang disetujui oleh menteri. Menteri dalam memberikan persetujuan litbang dapat memberlakukan ketentuan yang menurutnya sesuai atau dapat menetapkan jangka waktu untuk pengurangan.

Pasal 34B berisi mengenai pengurangan khusus untuk kontribusi ke lembaga penelitian yang disetujui atau pembayaran untuk penggunaan layanan lembaga atau perusahaan penelitian yang disetujui. Perusahaan perintis (pioneer status) tidak berhak mengklaim pemotongan ganda berdasarkan Pasal 34B dari ITA. Berdasarkan pasal ini, dalam rangka menyesuaikan pendapatan seseorang dari bisnis untuk basis periode satu tahun penilaian, pengurangan dapat dilakukan dari pendapatan kotor tahun tersebut yang berhubungan dengan pengeluaran dan bukan pengeluaran modal, yang dilakukan oleh orang tersebut selama periode yang bersangkutan. Pengurangan ganda dapat dilakukan dari pendapatan kotor bisnis selama pengeluaran tersebut berhubungan dengan:

a. kontribusi tunai kepada lembaga penelitian yang disetujui;

b. pembayaran untuk penggunaan layanan lembaga penelitian atau perusahaan penelitian yang disetujui;

c. pembayaran untuk penggunaan layanan perusahaan $R \& D$ kontrak dan perusahaan $\mathrm{R} \& \mathrm{D}$, atau perusahaan terkait yang ditetapkan.

Jumlah pengurangan yang dapat dilakukan berdasarkan Pasal 34A maupun 34B adalah dua kali lipat atau 200\% dari jumlah pengeluaran dan bukan termasuk belanja modal. Jika ada pengurangan untuk pengeluaran terkait litbang berdasarkan Pasal 34A maupun 34B, tidak ada pengurangan untuk pengeluaran berdasarkan 
Pasal 33 tentang adjusted income generally (pendapatan yang disesuaikan secara umum) maupun pasal 34 tentang special provisions applicable to adjusted income from a business (penerapan ketentuan khusus untuk pendapatan yang disesuaikan dari bisnis).

Departemen Pendapatan Thailand telah meluncurkan dua bentuk insentif pajak mengenai litbang sejak 1996. Bentuk insentif pertama adalah depresiasi khusus properti dalam kategori mesin dan aksesorisnya yang digunakan untuk penelitian dan pengembangan teknologi berdasarkan Royal Decree No. 319 tahun 1998. Depresiasi tersebut bisa dikurangkan pada tanggal akuisisi properti sebesar $40 \%$ dari total biaya akuisisi. Untuk nilai biaya sisa, pengurangan (deduction) dapat dibuat dengan memenuhi kriteria dan kondisi yang ditentukan. Mesin dan aksesoris yang digunakan harus memenuhi kriteria untuk mendapat pengurangan yaitu antara lain.

a. Mesin dan aksesorisnya tidak boleh digunakan untuk pembuatan barang atau penyediaan jasa, kecuali mesin atau aksesori digunakan untuk salah satu tujuan berikut:

1. penelitian industri dasar, yang berarti penelitian atau studi serius dengan tujuan untuk menemukan pengetahuan baru yang dapat bermanfaat bagi pengembangan produk, proses, atau layanan baru atau dengan tujuan untuk membuatnya kemajuan nyata pada produk, proses, atau layanan yang ada;

2. penelitian terapan, yang berarti perubahan hasil penelitian industri dasar ke dalam rencana kerja, cetak biru atau desain produksi, perubahan atau modifikasi produk, proses atau layanan baik untuk dijual atau digunakan sendiri, dan yang harus mencakup penemuan prototipe yang tidak dapat digunakan untuk tujuan komersial, konsep dalam persiapan dan desain produk, proses atau layanan, atau alternatif lain;

3. uji kualitas produk;

4. perbaikan proses produksi untuk mengurangi biaya produksi atau meningkatkan produktivitas. 
Mesin atau aksesori yang digunakan untuk penelitian dan pengembangan teknologi diperbolehkan milik sendiri atau orang lain.

b. Properti harus merupakan mesin dan aksesoris yang memang tidak dipakai dan mesin dan aksesori tersebut harus dapat digunakan selama dua tahun atau lebih dan memiliki nilai biaya tidak kurang dari 100.000 Baht.

Insentif kedua kedua adalah tunjangan pajak (tax allowance). Berdasarkan Royal Decree No.297, wajib pajak diberikan tambahan pemotongan sebesar $100 \%$ dari yang memenuhi syarat yaitu pengeluaran yang terjadi pada kegiatan R\&D yang dilakukan di Thailand dan pengeluaran yang dibayarkan kepada penyedia layanan R\&D yang disetujui. Pada tahun 2016, pemerintah mengeluarkan Royal Decree No. 598, yang bertujuan untuk memberikan tambahan pemotongan pajak menjadi sebesar 200\% untuk biaya R\&D yang sebelumnya sudah diatur dalam Royal Decree No.297 termasuk pengeluaran dibayarkan untuk meneliti dan mengembangkan teknologi dan inovasi untuk instansi pemerintah atau swasta yang ditetapkan oleh Direktur Jenderal. Insentif pajak berdasarkan Royal Decree No.598 efektif berlaku mulai 1 Januari 2015 hingga 31 Desember 2019. Royal Decree No.598 memberikan insentif pajak perusahaan untuk bisa membebankan biaya hingga sebesar $300 \%$ untuk R\&D dan inovasi selama 5 tahun. Namun, jumlah ini tidak boleh melebihi persentase pendapatan kotor di perhitungan laba bersih sebelum dikurangi biaya apapun dalam periode akuntansi tahunan. Pemotongan triple deduction diperbolehkan dengan dilakukan pembatasan yang dihitung berdasarkan pendapatan bruto seperti yang dijelaskan di bawah ini yaitu:

a. perusahaan dengan jumlah penghasilan tidak melebihi 50 juta Baht berhak atas pengurangan sampai dengan $60 \%$;

b. perusahaan dengan jumlah penghasilan melebihi 50 juta Baht tapi tidak melebihi 200 juta Baht berhak atas pengurangan sampai dengan 9\%;

c. perusahaan dengan jumlah penghasilan melebihi 200 juta Baht berhak atas pengurangan sampai dengan $6 \%$.

4.2.4 Yurisdiksi Pemajakan

Di Indonesia, berdasarkan PMK 153/PMK.010/2020, terhadap wajib pajak bisa diberikan penghasilan bruto dari biaya yang dikeluarkan untuk kegiatan litbang 
tertentu di Indonesia. Litbang yang dilakukan di luar negeri tidak dapat dikurangkan dari penghasilan bruto. Sementara itu, berdasarkan PMK 128/PMK.010/2019. Kegiatan vokasi yang memenuhi syarat dapat diberikan insentif pajak jika kegiatan tersebut dilakukan di Indonesia.

Di Malaysia, berdasarkan Public Ruling Nomor 5 dan 6 tahun 2020, yurisdiksi pemajakan terkait kegiatan litbang yaitu kegiatan litbang yang dilakukan baik di Malaysia maupun luar negeri. Untuk kegiatan litbang berupa layanan teknis yang dilakukan di luar Malaysia harus mendapat persetujuan Menteri Keuangan. Sementara itu, untuk kegiatan vokasi berdasarkan Income Tax Act 1967, yurisdiksi pemajakan terkait vokasi yaitu kegiatan vokasi yang dilakukan di dalam negeri.

Di Thailand, berdasarkan Tax Revenue Code 1938, kegiatan R\&D yang dilakukan oleh wajib pajak dapat diberikan insentif pengurangan jika dilakukan di dalam negeri.

\subsubsection{Wajib Pajak yang Berhak Membebankan Biaya yang Dikeluarkan}

Di Indonesia, wajib pajak yang berhak membebankan biaya terkait dengan fasilitas super deduction tax berdasarkan PMK 153/2020 dan PMK 128/2019 yaitu wajib pajak badan dalam negeri yang melakukan kegiatan litbang maupun vokasi tertentu di Indonesia. Di Malaysia, berdasarkan Promotion of Investment 1986, wajib pajak yang berhak memanfaatkan insentif yaitu badan usaha yang melakukan kegiatan litbang dan memenuhi syarat serta perusahaan pelatihan teknis atau kejuruan dan institusi pendidikan tinggi swasta memenuhi syarat. Di Thailand, berdasarkan Tax Revenue Code 1938, badan usaha untuk semua jenis industri boleh membebankan biaya R\&D yang dikeluarkan untuk usahanya. Sementara itu, badan usaha yang berhak memanfaatkan insentif vokasi hanya badan usaha yang memenuhi syarat.

\subsubsection{Kompensasi Kerugian}

Berdasarkan UU PPh, apabila penghasilan bruto di Indonesia setelah dikurangi dengan biaya yang dapat dibebankan didapat kerugian, kerugian tersebut bisa dikompensasikan ke masa pajak berikutnya sampai dengan lima tahun secara berturut-turut. 
Berdasarkan Income Tax Act 1967, apabila pada suatu tahun pengeluaran R\&D perusahaan di Malaysia melebihi pendapatan usaha, kelebihan pengeluaran tersebut dapat dikompensasi ke tahun berikutnya (carry forward).

Berdasarkan section 65 Revenue Code Thailand, kerugian operasi perusahaan termasuk karena kegiatan litbang maupun vokasi dapat dibawa ke depan (carry forward) selama lima periode akuntansi untuk dikompensasikan dengan keuntungan perusahaan. Namun, tidak ada penyisihan untuk pengembalian kerugian ke periode akuntansi sebelumnya.

\section{KESIMPULAN}

Berdasarkan pembahasan pada bab sebelumnya mengenai perlakuan insentif super deduction tax di Indonesia dan perbandingannya dengan Malaysia dan Thailand, penulis mengambil kesimpulan sebagai berikut:

1. Pemerintah RI mengeluarkan Peraturan Pemerintah Nomor 45 Tahun 2019 rangka mendorong investasi pada industri padat kerja. Peraturan ini merupakan kebijakan insentif super deduction tax pertama yang memberikan pengurangan melebihi $100 \%$ dari biaya atas kegiatan pemagangan maupun litbang. Selanjutnya, Pemerintah mengeluarkan PMK 128/PMK.010/2019 mengenai pemberian insentif pengurangan untuk kegiatan pemagangan, praktik kerja, maupun pembelajaran. PMK ini memberikan pengurangan penghasilan bruto hingga 200\%. Pada tahun 2020, Pemerintah mengeluarkan PMK 153/PMK.010/2020 mengenai insentif pengurangan untuk litbang. PMK ini memberikan fasilitas pengurangan kegiatan litbang tertentu di Indonesia hingga $300 \%$.

2. Malaysia memberikan insentif super deduction tax terkait litbang berupa pengurangan ganda sebesar 200\% (double deduction) atas pengeluaran nonmodal dan pembayaran ke penyedia jasa R\&D yang disetujui Menteri Keuangan. Biaya yang dapat dibebankan yaitu antara lain gaji, perlengkapan, layanan teknis, biaya teknis, biaya transportasi, biaya pemeliharaan, dan sewa. Selain itu, pemerintah Malaysia memberikan insentif investment tax allowance (tunjangan pajak investasi) untuk perusahaan R\&D dan R\&D kontrak sebesar 
$100 \%$ dan untuk perusahaan in-house R\&D sebesar 50\% dalam jangka waktu 10 tahun jika memenuhi syarat. Terkait vokasi, pemerintah memberikan insentif investment tax allowance untuk perusahaan pelatihan teknis atau kejuruan dan institusi pendidikan tinggi swasta sebesar $100 \%$ dalam jangka waktu 10 tahun jika memenuhi syarat.

3. Thailand memberikan insentif super deduction tax terkait litbang berupa pengurangan sebesar $300 \%$ (triple deduction) dari biaya yang dikeluarkan untuk kegiatan R\&D di Thailand, pembayaran ke penyedia layanan R\&D, dan pembayaran ke instansi pemerintah dan agen swasta tertentu. Biaya yang dapat dibebankan yaitu antara lain biaya terkait penelitian dasar, penelitian terapan, dan penelitian pengembangan eksperimental sesuai OECD Frascati Manual.Selain itu, pemerintah juga memberikan insentif berupa akselerasi penyusutan mesin dan peralatan yang bisa dibebankan sebesar $40 \%$ saat akuisisi. Terkait vokasi, pemerintah memberikan insentif berupa Royal Decree No.711 berupa pengurangan sebesar $150 \%$ untuk gaji karyawan yang memiliki sertifikasi keahlian, Royal Decree No.712 berupa pengurangan sebesar 250\% untuk pendidikan atau pelatihan karyawan, dan Royal Decree No.713 berupa pengurangan sebesar $200 \%$ untuk donasi ke institusi pendidikan.

4. Berdasarkan komparasi kebijakan pemberian insentif super deduction tax, Indonesia, Malaysia, dan Thailand memiliki tujuan yang sama untuk mendorong kegiatan litbang yang masif di negara masing-masing dan memajukan sektor vokasi nasional yang berperan penting dalam memajukan ekonomi. Hal ini tercermin dari yurisdiksi pemajakan terkait pemberian insentif di ketiga negara yang hanya bisa diberikan jika kegiatan litbang atau vokasi tersebut dilakukan di dalam negeri. Setiap negara memiliki kebijakan tarif pengurangan pajak yang berbeda sesuai kebutuhannya dan tentu memiliki fokus kegiatan yang berbeda juga. Insentif yang dikeluarkan tentu dirancang untuk tidak merugikan wajib pajak. Kerugian usaha di ketiga negara tersebut dapat dikompensasikan ke masa pajak berikutnya dan untuk Indonesia dan Thailand kerugian usaha dapat (carry forward) dibawa selama lima periode akuntansi untuk dikompensasikan dengan keuntungan usaha. 


\section{KETERBATASAN DAN SARAN}

Dalam melakukan penelusuran dan perolehan data, penulis mengalami kesulitan untuk memperoleh peraturan-peraturan yang relevan terkait insentif super deduction tax terutama di negara Malaysia dan Thailand. Penulis tidak bisa sepenuhnya mendapatkan sumber referensi dan pandangan ahli di negara Malaysia dan Thailand karena di beberapa website negara tersebut hanya menyajikan konten berbahasa negara masing-masing. Saran yang bisa penulis berikan yaitu memaksimalkan sumber referensi yang ada dan menggali informasi dari narasumber/tokoh ahli Indonesia di bidang perpajakan.

\section{DAFTAR PUSTAKA}

Darussalam, \& Tobing, G. C. (2013). Insentif Pajak Penghasilan atas Biaya Penelitian dan Pengembangan. Jakarta: DDTC.

Daryanto. (2009). Panduan Proses Pembelajaran Kreatif \& Inovatif teori \& Praktek Pengembangan Dalam Profesionalisme Bagi Guru. Jakarta: CV AV Publisher.

Dipang, L. (2013). Jurnal EMBA: Riset Ekonomi, Manajemen, Bisnis, dan Akuntansi. Pengembangan Sumber Daya Manusia dalam Peningkatan Kinerja Karyawan, 1080-1088.

Hapsari, S. A. (2020, Juli 7). Karya Tulis Tugas Akhir. Tinjauan Perlakuan Insentif Super Deduction Tax: Studi Komparasi Indonesia, India, China, dan Singapura. Tangerang Selatan, Tangerang, Indonesia: PKN STAN.

International Monetary Fund. (2020). World Economic Outlook: A Crisis Like No Other, An Uncertain Recovery. Washington, D.C.: IMF.

Irwanto. (2020, September 11). Abstract: Comparative Study of Tax Incentives in Indonesia, Malaysia, and The United State of America to Support Research and Development. Dipetik Desember 31, 2020, dari UPH Repository: http://repository.uph.edu/9963/

Kementerian Perindustrian. (2016, November 29). Lima Menteri Teken MoU Pengembangan Pendidikan Vokasi. Diambil kembali dari Siaran Pers Kemenperin: https://kemenperin.go.id/artikel/16633/Lima-Menteri-Teken-MoU-PengembanganPendidikan-Vokasi

Mondy, W. (2008). Manajemen Sumber Daya Manusia. Jakarta: PT Gelora Aksara Pratama.

OECD. (2015). Frascati Manual 2015: Guidelines for Collecting and Reporting Data on Research and Experimental Development. Paris: OECD Publishing. 
PISA. (2015). Programme For International Student Assessment (PISA) Result from PISA 2015. Paris: Directorate of Education and Skill.

PISA. (2018). Programme For International Student Assessment (PISA) Result from PISA 2018. Paris: Directorate for Education and Skills.

Sugiyono. (2012). Metode Penelitian Pendidikan Pendekatan Kuantitaif, Kualitatif, dan $R \& D$. Bandung: Alfabeta.

World Bank. (2020). The Human Capital Index (HCI) 2020 Update: The Human Capital in the Time of Covid-19. Washington, D.C.: World Bank Group.

World Bank. (n.d.). Research and Development Expenditure (\% of GDP). Retrieved November 15, 2020, from UNESCO Institute for Statistics: https://data.worldbank.org/indicator/GB.XPD.RSDV.GD.ZS 